\title{
Marija Kozar-Mukič
}

(Sombotel, Madžarska)

\section{PREVZETE BESEDE V PORABSKIH LJUDSKIH PESMIH}

\begin{abstract}
Adopted words and phonetical characteristics of the common Slovene language in the folk songs of the Raba-region prove that the Slovenes in the neighborhood of Szentgotthárd had the most contacts with Slovenes and Germans in the Austrian Steiermark. A few words were adopted from Croatians and hardly any from Hungarians.
\end{abstract}

Keywords: folk songs, Slovenes in Hungary, adopted words

Pred prvo svetovno vojno so prinašali $\mathrm{v}$ devet slovenskih vasi $\mathrm{v}$ okolici Monoštra ${ }^{1}$ največ novih pesmi hlapci in dekleta, ki so se vračala $\mathrm{z}$ dela, romarji in sezonski delavci. V prvi svetovni vojni so fantje iz teh vasi bili na raznih frontah skupaj z vrstniki različnih narodov Avstro-ogrske monarhije, tako tudi Slovenci. Od njih so se naučili vojaške in ljubezenske pesmi in s pesmimi vred prevzeli tudi besede iz splošnoslovenskega jezika. V letih 1945-1946 so v Porabje hodili slovenski partizani iz Prekmurja. Tudi od njih so se učili Porabci pesmi, ki so jih peli in prepisovali ob lupanju bučnih semen in česanju perja ter drugih prilikah. ${ }^{2}$

Besede iz splošnoslovenskega jezika se pojavljajo še v cerkvenih pesmih, ki so jih duhovniki prevzeli iz »kranjskih« molitvenikov. Ali so se jih ljudje naučili na romanjih. Na sezonskem delu so Slovenci delali skupaj s Hrvati, tako se pojavljajo $\mathrm{v}$ pesmih tudi hrvaške besede. Nemške besede so prevzeli na začasnem delu v Gradcu in drugih krajih avstrijske Štajerske.

$\mathrm{V}$ pregledanih dvesto porabskih pesmi v zbirki Füčkaj, füčkaj, fantiček moj (Mukič 2001 in 2003) smo iskali neporabske besede in besedne zveze, jezikovne pojave, ki niso značilni za porabsko narečje. Te besede včasih niti niso razumeli in tako tudi popačili ali nadomestili $\mathrm{z}$ domačo besedo (npr. tramvaj s taligami/samokolnico, nočnica $\mathrm{z}$ noč nocoj ipd).

\section{Izrazi splošnoslovenskega jezika v ljubezenski pesmih in baladah}

Največkrat se pojavi beseda fant, fantič, fantiček in jaz. Prevzete besede so v veliki večini samostalniki, le nekaj je glagolov.

Primeri:

${ }^{1}$ Gornji Senik, Dolnji Senik, Sakalovci, Slovenska ves, Števanovci, Otkovci, Verica, Ritkarovci, Andovci.

${ }^{2}$ prim. rokopisno pesmarico družine Bajzek na Gornjem Seniku, v kateri je dvajset takih pesmi. Marija Kozar-Mukič: Gradivo za slovensko narodnoosvobodilno pesništvo. Jezik in slovstvo, letnik XXIII, leto 1977/78, št. 1, str. 29-30. 
barka pisana $(93)^{3}$, bejli grad (90), bistra voda (93), bolan (53), brezi vse skrbi (39), fant $(2,90,158,193,200)$, fanta $(29,30,51)$, fante $(43,89)$, fanti $(35,103)$, fantič $(23,31,50,54,73,74,139,156)$, fantiček $(37,49,67,176)$, fantov (37), gleda si dol krasé ('okrase' 140), gomilico (79), gomilo (41), Gorenjsko (120), goričice (44), hišico (30), jaz (34, 96, 117/3, 140, 144, 157, $158,165,166,183,189,192)$, kje (127), kleti (37), klobuček (144), končecom ('s sukancem' 144), konjička (54), konjički škrebljajo (184), kovran (gavran, krokar 169), Kranjci (35), krasna je nočnica ('noč nocoj' - 76), ladja (14), Lublanca ('Ljubljana' 176), lunica (52), mladenec (20), mrtve kosti (124), na bližnjem hribčku (168), na goro visiko (88), na morje veslat (76), na okecne potrkam (74), na vasi (168), nocoj (67), norica (52), obložen (184), očka (140), odgovor (139), opsida ('obseda - omizje' 149) ovce (154), ovčar (154), pelin (129), pelinovec (155), petelinček (74), petelinčke (90), plamince (101), plaminčice (44), po cest' (157), pomlad (77), prebudičke (90), pred gostilno (40), pred sovragom (100), pretemne so noči (74), raubček (150), robček (49), robec (5), Rovanci=Hrvatje (35), samostan (88), skupaj (168), stezice (74), šimlina (54), ulica (190), ur'ca (90), v bistroj vodici (14), v daljavi (100), v kraje tuje (100), v valauve (51), vendar (74), vina je štrihan glaž ('do roba poln' 118), vol (169), vrt (127), z globočin (35), z gornjega kraja (52), zaročnico (101),

Pesniška beseda »gavran« za krokarja v obliki »kovran« se je ohranila v pesmi Sestrica, stani, na pašo boš šla (169). To je porabska inačica pesmi o hudičevi nevesti. Brat je sestro zaklel v pekel, ker ni hotela zgodaj zjutraj živino na pašo gnati. Med oranjem dobi tri sporočila. Tretjič mu črn gavran sporoči, da se sestra poroča. Ko se brat zvečer vrne domov, sestro že hudič pelje s kočijo k poroki.

Glagoli: dekline zapaja - (zavaja 52), govori (124), gre (157), greta $(22,68)$, grem (74), karte vržejo (89), kregajo (186), mimo gre (139), nesrečna bla (52), me kregajo (140), odgovor dati (58), odromala (83), pela (21), poglej (166), pojde (120), pojdejo (176), pojdeta (22), pojem (140), pojo (162), prašau ('vprašal' 37), 'prašat ('vprašat' 164), preklela (37), premaguje (100), prihajo (162), pustaj ('pusti' 40), reko ('rekel' 176), se priklatim (74), sem rekeu (57), spomnite se kdaj (100), sprašuješ (156), spremlevale ('spremljevale' 100), sunce potemnelo (52), šeu bom (164), štandero ('študiral' 53), zanosila (50, 139), zvejzde bleščale (100), zvonovi nemilo pojo (101), žvrgoli (77).

Glagol »študirati« se pojavi v baladi Moj oča méu je sine tri. Oče je imel tri sinove, da bi mu bili v pomoč na stara leta. Toda vsi trije še mladi umrejo. Prvi je bil študent, ki je študiral dvanajst let, na trinajsto je moral umreti. Drugi je bil vojak, ki je služil osem let, na deveto je moral umret. Tretji pa je zbolel, leto dni je ležal in si je smrti sam želel.

\footnotetext{
${ }^{3}$ V oklepaju je številka pesmi v zbirki Füčkaj, füčkaj, fantiček moj
} 


\section{Izrazi splošnoslovenskega jezika v vojaških pesmih}

Tudi pri vojaških pesmih se največkrat pojavi beseda fant, fantič, fantiček in jaz. V veliki večini so samostalniki, le nekaj je glagolov.

Primeri:

bejle lunce (87), cesta (62), desnica (138), dober dan (196), Donava (105), fant $(9,17,18,87,138,179,196)$, fantič $(15,18,36,106,128,178,196)$, fantiček (19, 138), gora (177), iz tujine (36), jaz (128, 133, 138, 173, 174), junak (145), kasarne (15), mladenec (112), Morava (105), mreža (62), na desno stran (128), na gmajnici (18), na straži stoji (137), nočnica (36), obrambica (18), ostri meč (134), plamina (36), polenta (9), poljubček (62), potrta (62), s Kranjske doline (17), stalno (137), stražar (62), vu tabori (138), vislice (105), vojakov (91), $k$ vojski (19), na vojskoj pauli (13) vrt (172).

»Polenta" niti kot beseda, niti kot hrana ni znana v Porabju. Pesem Dekle ide nutri v püngrad je najbrž nastala za časa prve svetovne vojne, $v$ kateri so ogrski Slovenci prišli do Italije, »na taljanski front«. Kot vojaki avstro-ogrske armade pretijo Italjanom: »Čakaj ti taljanska fara/vej ti mi pokažemo./Kak se more polenta pečti [...]. S kruglami ti osolimo/s štükom ti jo načnemo.«

Glagoli: časi hitijo, preminijo (36), govori (92), govorit (36), obimam ('objemam' 36), odhajati (87), plavam (138), potrkat (36), razprestrem (36), se glas razširi (92), so zagrnole (13), tekla moja zibelka (36).

\section{Hrvaški izrazi v porabskih ljudskih pesmih}

Primeri:

daleko (137), dečica (45), deklič (158), devojčica (54), divojka (102), divojka (44), dopadnola (83), ftičice grličice (158), jabuka redeča (119), jakša (135), jakša (30), jakše (59), jakše (85), jakšo (72), jeli (45), jesi (164), kaput (88), kiša pada (33), kuma (142), ljubav (115), ljubav žarko (137), naj si ga podišim (192), najjakša deklina (21), otvori (115), raužica rumena (165), se šetam (192), (zlate) slove piše ('slovo - črka' 99), spava (42), spavaj (88), spavat (176), spavo (17), stazica (115), šetala (146), zapitala (33), zazovala (76), žarke skuze (18).

Porabski Slovenci so imeli stike s Hrvati preko duhovnikov in na sezonskem delu. Ljudske pesmi so prevzeli od Hrvatov večinoma na sezonskem delu. Cerkvene pesmi pa doma od duhovnikov. Pesem »Micika moja« je tudi po vsebini dalmatinska, ne samo po besedah. Fant ljubosumno misli na dekle iz velike daljave. Pritožuje se tudi zaradi siromaštva: »Nemam nikoga, samo eno malo barko,/in ljubav žarko do Marice.»

\section{Nemški izrazi v porabskih ljudskih pesmih}

Primeri: ajnc, cvaj, draj (1), farbo (55), jungfrajla (70), lump (88), na štauki (42), Ober Štajersko (120), pinten glaž (69), po španceranji (192). pofrišala (144), rajtaš (135), šauštar (113), šnajder (113), šnajder (66), špancer (112), špancer (20), špancera (90), šrajb papir (4), štauka dva (30), štauke iže (30), 
štimaš (135), štinglic (9), štrikala (88), šujster (66), ti šajni guti nau (die schöne gute Nacht! - 175), tišlar (113), v špitalaj (35), vina štrinjem glaž (69).

Porabski Slovenci so kot hlapci in dekleta služili pri kmetih na avstrijskem Štajerskem. Zaposlovali so se tudi kot delavci v tovarnah v Gradcu. Z obrtniki iz sosednje Štajerske so prihajala $\mathrm{V}$ Porabje in porabščino tudi njihova poimenovanja: šauštar, šujster - čevljar, šnajder - krojač ipd. V ljubezenski pesmi Stari hergolin je celo nemški stavek, čeprav je popačen: ti šajni guti nau (die schöne gute Nacht! (175)

\section{Madžarski izrazi v porabskih ljudskih pesmih}

Primeri: dž̈̈nževna (149) (m. gyöngyös) 'biserna', huncvut (167) (m. huncut) 'prebrisan', kinč (124) (m. kincs) 'zaklad', parta (149) (m. párta) 'trak', šikšak (114) (m. sisak) 'čelada'.

V porabski ljudski pesmi je najmanj madžarskih izrazov. Pesem $O, z d a j$ moja opsida (omizje) je ženitovanjska iz 19. stoletja. Prevedena ali prirejena iz madžarččine. "parta džünževa« je kalk po madžarski besedi »gyöngyöspárta«.

\section{Glasoslovni pojavi, ki jih porabščina ne pozna}

Soglasnik $h \mathrm{v}$ porabščini na začetku besede onemi. Besede, v katerih se $h \mathrm{v}$ porabskih pesmih izgovarja, so prevzete iz splošnoslovenske leksike.

Primeri: hodila (20), hod'mo (118), hišo (151), hiš'ca (164), hodi (164), vu hiši (164), hitro zbeži (92), za hrbtom (92), hodila (112), hodi (196).

Zvočnik $j$ se $\mathrm{v}$ porabščini na začetku besede ali med samoglasniki izgovarja kot mehki $d$ '. Besede, ki se začenjajo z $j$ in se med samoglasniki izgovarja $j$, so prevzete iz splošnoslovskega jezika.

Primeri: jamico (79), jamo (91), jesen (196).

Prevzete besede in glasoslovne značilnosti splošnoslovenskega jezika $\mathrm{v}$ porabskih ljudskih pesmih pričajo o tem, da so imeli Slovenci v okolici Monoštra največ stikov s Slovenci in Nemci na avstrijskem Štajerskem. Nekaj besed so prevzeli od Hrvatov zelo malo pa od Madžarov. Pri ohranjanju materinščine in lastne kulture Slovencev na Madžarskem so ljudske pesmi igrale pomembno vlogo skozi stoletja in so tudi danes sredstvo za krepitev identitete.

\section{Literatura}

Mukič, F. (2001) in D. Füčkaj, füčkaj, fantiček moj. Sto ljudskih pesmi iz Porabja. Zveza Slovencev na Madžarskem. Szombathely.

Mukič, F. (2003) in D. Füčkaj, füčkaj, fantiček moj 2. Še sto ljudskih pesmi iz Porabja. Zveza Slovencev na Madžarskem. Szombathely.

Zorko, Z. (2005) Prekmursko narečje med Muro in Rabo na vseh jezikovnih ravninah primerjalno $\mathrm{z}$ današnjim nadnarečnim prekmurskim knjižnim jezikom. Prekmurska narečna slovstvena ustvarjalnost. Ustanova dr. Šiftarjeva fundacija Petanjci. Murska Sobota, 47-66. 